\title{
The Rate of Metabolism and Performance of Broiler Who Gets Skin Treatment Rations Containing Cassava Flour and Injection Solution Thyroid Gland
}

\author{
Yuanita Windusari, Meisji Liana Sari, Sofia Sandi S., and Agus Budiyansyah
}

\begin{abstract}
The aims of this research was to find out the effect of the thyroid gland flour given by injection and skin cassava flour given in the diet on metabolic rate and performance of broiler chickens. Feeds were arranged with protein content $(18 \%)$ and metabolism energy $(2900 \mathrm{kcal} / \mathrm{kg})$ in accordance with recommendations of Nutrition Research Council (NRC). As many as 35 were one week old chicks used in this study. Completely random design was used in this research, with 5 treatments and 4 replicates. Each of these repeats was placed 3 ducks and kept for 3 months. The treatment consisted of $P 1$ (control diet), P2 $(\mathbf{7 0} \%$ basal diet $+30 \%$ cassava peel without steam), P3 $(100 \%$ basal ration with treatment of the thyroid gland injection of starch solution as much as $10 \mathrm{mg}$ per day in subcutaneous), P4 (100\% basal ration with treatment of the thyroid gland flour solution injection of $20 \mathrm{mg}$ per day in subcutaneous). The results showed that metabolic activity of broilers increased concurrently with the increasing age characterized by increased oxygen consumption, body heat production and basal metabolic rate.
\end{abstract}

Index Terms-Countaining casava flour, solution tyroid gland, chicken.

\section{INTRODUCTION}

Endocrine system in the body serves to unify and harmonize the various processes and systems in the body, thus allowing the changes according to environmental conditions. This integration by hormone produced by certain glands in the body and transported to target cells with circulation. Thyroid hormone is one of the endocrine systems in the body. In the active form of thyroid hormone is as tri-iodothyronine (T3) and thyroxine (T4) has an important role in the physiology of the body, such as in growth, reproduction, metabolism and other foods. Thyroid hormone stimulates protein synthesis in tissues that synthesize RNA at the core level [1].

Therefore it can be said to affect thyroid hormone metabolism controls the general. Synthetic thyroid hormone is a substance that supposedly could provide benefit when given to chickens. This is because the nature of thyroid hormone like noted above, so that could be expected to increase the rate of metabolism and performance of broiler

Manuscript received July 8, 2013; revised December 20, 2013

Yuanita Windusari is with the Department of Biology, Faculty of Mathematics and Natural Sciences, Sriwijaya University, South Sumatera, Indonesia (e-mail: ywindusari@yahoo.com).

Meisji Liana Sari and Sofia Sandi S. are with the Department of Animal Science, Faculty of Agriculture, Sriwijaya University, South Sumatera, Indonesia (e-mail: meisji@yahoo.com).

Agus Budiyansyah is with Faculty of Animal Science, Jambi University, Indonesia (e-mail: budiansyah_agus@yahoo.com). chickens, as well as synthetic thyroid hormone can increase the activity of the thyroid gland to produce thyroid hormones in broiler chickens. However, data on the number or doses that can be given to broiler chickens is not known for sure. Therefore, the research about the right amount or dose of a synthetic thyroid hormone use in broiler chickens needs to be known.

On the other hand the use of certain materials that are goitrogenik can inhibit mineral absorption of iodine by the thyroid gland, resulting in the formation of hormones from the thyroid gland is inhibited. It is known that the formation of the mineral iodine is a component of thyroid hormones. Raw foods are goitrogenic among others are derived from cassava (including bark, tubers and cassava leaves). This is due to the material containing cyanide $(\mathrm{HCN})$. Thiocyanate, the results of cyanide ion detoxification of $\mathrm{HCN}$ in the heart will inhibit absorption (uptake) in the blood iodine by the thyroid gland.

This study was conducted to determine the effect of the thyroid gland flour given by injection and skin cassava flour given in the diet on metabolic rate and performance of broiler chickens.

\section{MATERIALS AND METHODS}

\section{A. Materials Research}

A total of 35 were one week old chicks used in this study. Another material used is the thyroid gland flour dissolved in distilled water with a concentration of $10 \mathrm{mg}$ and $20 \mathrm{mg}$ per $0.5 \mathrm{cc}$ for one injection every day and calculated based on the need for injection for 7 days. Ration ration used was compiled based on the needs of the chicks initial period under the recomendations of the Nutrition Research Council 1994 were compiled using materials yellow corn, fish meal, coconut meal, fine bran, soybean meal, bone meal and premix and feed ingredients cassava peel which is steamed and dried with the treatment without steamed. Weighing both the chicks and feed treatments using Ohaus digital scale brands with a level of accuracy 0.0001 grams.

Use measure oxygen consumption Calorimeter chamber made of jar equipped with a rubber hose and a syringe to measure the volume of incoming air, pipe manometer scale U-shaped letters made of glass and $\mathrm{NaOH}$ solution as the absorbent. To measure oxygen consumption when used timekeeping device (timer).

\section{B. Research Methods}

A total of 10 chicks aged one week to judge the rate of metabolism by measuring oxygen consumption and heat 
production of the body by using the system to determine the rate of metabolism beginning of broiler chickens. A total of 25 chicks then maintained for one week to be given five (5) kinds of treatment. Each treatment performed in 5 (five) chicks. These five kinds of treatment are:

P1 : Chickens fed control diet (100\% basal ration)

P2 : Chickens fed rations containing dried cassava peel without steamed as much as $30 \%(70 \%$ basal diet $+30 \%$ cassava peel without steam) Chickens fed rations containing dried cassava peel without steamed as much as 30\% (70\% basal diet $+30 \%$ cassava peel without steam)

P3 : Chickens fed rations containing skin-dried cassava steamed prior treatment by $30 \%(70 \%+$ $30 \%$ basal ration skin steamed cassava)

P4 : Chickens fed control diet (100\% basal ration) with treatment of the thyroid gland injection of starch solution as much as $10 \mathrm{mg}$ per day in subcutaneous

P5 : Chickens fed control diet (100\% basal ration) with treatment of the thyroid gland flour solution injection of $20 \mathrm{mg}$ per day in sub-cutaneous;

Basal ration composition and nutrient content of the diets are presented in Table I.

TABLE I: THE COMPOSITION OF FEED INGREDIENTS MAKING UP THE BASAL RATION

\begin{tabular}{|c|c|}
\hline Composition of feed ingredients & $(\%)$ \\
\hline Fine bran & 8.5 \\
\hline Yellow corn & 54.0 \\
\hline Soybean meal & 15.5 \\
\hline Fish meal & 13.4 \\
\hline Coconut cake & 6.5 \\
\hline Vegetable oil & 2.0 \\
\hline Top mix & 0.1 \\
\hline Total & 100 \\
\hline Metabolizable energy $(\mathrm{kcal} / \mathrm{kg})$ & 3001 \\
\hline Crude protein $(\%)$ & $21: 2$ \\
\hline Crude fat $(\%)$ & $11: 13$ \\
\hline Crude fiber $(\%)$ & $3: 56$ \\
\hline Calcium (\%) & $1: 25$ \\
\hline
\end{tabular}

Before being given treatment, chicks were weighed beforehand to determine initial body weight. Weighing of body weight every day in the morning. Rationing and performed daily drinking water ad libitum. Daily feed intake was measured by weighing before being given rations and rations remaining after 24 hours of administration. Feed intake is calculated based on the difference given rations and rations rest. Body weight gain was calculated based on daily body weight gain. After one week, the chicks back measurements performed by measuring the metabolic rate of oxygen consumption and heat production of the body.

Measurement of oxygen consumption and Heat Production Rate Metabolism Oxygen consumption measurements conducted using a closed-circuit system using a Calorimeter chamber in the form of jars and equipment. Put chicks into a jar, then sealed and airtight. Before the chicks put in a jar, tube manometer scale has been filled with water as a control tool that the volume of oxygen consumed is entered already. To absorb the carbon dioxide released by the oxidation of the rest of the chicks, at the bottom of the jar is placed in a bottle $\mathrm{NaOH}$ grain size of 10 cc. A number of oxygen volume syringe is inserted through a predetermined volume (initial measurement is $15 \mathrm{cc}$ and $20 \mathrm{cc}$ ). One of the air intake causing the water level in the pipe manometer rose motivated by the pressure of air entering through the pipe. The beginning of time through the syringe air intake recorded, and after the water level in the capillary equal end time is recorded as the volume of oxygen consumed. During the measurement of oxygen consumption, air temperature (T1) and pressure (P1) is recorded, as well as the existing state of chicks observed in jars. Oxygen consumption (V1) standardized at $760 \mathrm{~mm} \mathrm{Hg}$ pressure (P2) at a temperature of $273{ }^{\circ} \mathrm{K}$ (T2). Oxygen consumption (V2) is calculated with the formula P1V1/T1 = $\mathrm{P} 2 \mathrm{~V} 2 / \mathrm{T} 2$. Heat production was calculated based on oxygen consumption multiplied by the equivalent calorific value. On chickens that are given feed with a mixture of carbohydrates, fat and protein, equivalent calorific value standardized to the value of $4.825 \mathrm{Kcal} /$ liter of oxygen consumed. Chicks' basal metabolic rate is calculated based on the body's production of heat per gram of metabolic body weight per day (0.75 g BB / day).

Observed Variables Parameters observed in this penlitian include oxygen consumption (liters / head / day), body heat production ( $\mathrm{kcal} / \mathrm{head}$ day), basal metabolic rate (kcal / 0.75 g BB / day), feed intake (g / day), body weight gain (g / day) and feed conversion.

Data processing Research using completely randomized design (CRD) with 5 treatments and 5 replications. Data were processed using variance used in accordance with the design by using the SAS program. To test for differences between treatment used Duncan's multiple range test [2] and also using the SAS program.

\section{RESULTS AND DISCUSSION}

\section{A. Effect of Treatment of Metabolic Rate}

Treatment effect on oxygen consumption, body heat production and basal metabolic rate are presented in Table II. Results of analysis of variance showed that the treatment significantly $(P<0.05)$ on oxygen consumption and heat production of broiler chicken's body, but did not significantly affect the basal metabolic rate. Based on the results of Duncan's multiple range test (Table II) showed that the oxygen consumption and heat production in chickens treated with diet containing cassava peel as much as $30 \%$ (either steamed or without steamed) was significantly higher than that of chickens that received control treatment, but the consumption of oxygen and production of body heat from the chickens given the treatment of thyroid powder injection solution as much as 10 $\mathrm{mg} /$ head / day or $20 \mathrm{mg} /$ head / day was not significantly different than the control treatment. This means cassava significantly increased oxygen consumption and heat 
production of broiler body whereas no effect of thyroid powder.

TABLE II: THE AverAge TREATMENT EFFECT ON OXYGEN CONSUMPTION, Heat PRoduction and the Body's Basal Metabolic Rate of BroIler

\begin{tabular}{|c|c|c|c|}
\hline \multirow{2}{*}{ Treatment } & \multicolumn{3}{|c|}{ CHICKENS } \\
\cline { 2 - 4 } & $\begin{array}{c}\text { Oxygen } \\
\text { Consumption } \\
\text { Liters / head / } \\
\text { day) }\end{array}$ & $\begin{array}{c}\text { Body Heat } \\
\text { Production } \\
\text { (Kcal / head / } \\
\text { day) }\end{array}$ & $\begin{array}{c}\text { Basal } \\
\text { Metabolic Rate } \\
\text { (Kcal / g } \\
\text { BB0.75/hari) }\end{array}$ \\
\hline $\begin{array}{c}\text { Early (age 7 } \\
\text { days) }\end{array}$ & $3,2352^{\mathbf{c}}$ & $15,6106^{\mathbf{c}}$ & 4,44 \\
\hline P1 (Control) & $4,807^{\mathbf{b}}$ & $22,231^{\mathbf{b}}$ & 3,46 \\
\hline $\begin{array}{c}\text { P2 (cassava skin } \\
\text { without steam) }\end{array}$ & $6,266^{\mathrm{a}}$ & $30,236^{\mathbf{a}}$ & 4,34 \\
\hline $\begin{array}{c}\text { P2 (skin on } \\
\text { steamed manioc) }\end{array}$ & $6,266^{\mathrm{a}}$ & $30,236^{\mathrm{a}}$ & 4,58 \\
\hline $\begin{array}{c}\text { P4 (Flour thyroid } \\
10 \text { mg / head / } \\
\text { day) }\end{array}$ & $5,1867^{\text {ab }}$ & $25,027^{\text {ab }}$ & 4,75 \\
\hline $\begin{array}{c}\text { P5 (Flour thyroid } \\
\text { 20 mg / head / } \\
\text { day) }\end{array}$ & $5,081^{\text {ab }}$ & $24,516^{\text {ab }}$ & 3,62 \\
\hline
\end{tabular}

Description: Superscript lowercase letters are different at the same column indicate significantly different at the level of $(P<0,05)$.

Oxygen consumption and increased body heat production due to rationing containing cassava $\mathrm{HCN}$ suspected toxic effect on the body's metabolism in chickens. The chickens will speed up the process of respiration to consume more oxygen to oxygen consumed can be transported by the blood to the liver to be used in the oxidation of food substances. This is due to $\mathrm{HCN}$ will bind minerals mineral $\mathrm{Fe} F$ that cannot bind to oxygen and oxygen can be transported by the blood. As a result of body heat production will also rise.

In addition to the basal ration replacement of cassava flour will increase the carbohydrate content of the ration so that the energy metabolism in the body faster than the chickens that received carbohydrate diets lower. It is known that the equivalent calorific value is higher carb than protein. On chickens that are subjected to administration of thyroid powder as much as $10 \mathrm{mg} / \mathrm{head} / \mathrm{day}$ and $20 \mathrm{mg} / \mathrm{head} /$ day, oxygen consumption and heat production of the body is not significantly different than the chickens that received the control treatment, but there is a tendency that the oxygen consumption and body heat production is higher than the control treatment. This means that there is a tendency to an increase in metabolic activity by administration of thyroid powder. This is due to the thyroid hormone works to increase energy and stimulate metabolism enzymes are closely linked to energy metabolism to digest nutrients [3]. The process resulted in a number of metabolic energy in the form of ATP, and ATP will be used by the body to increase metabolism and activity.

Overhaul of food substances in the body held by mmerlukan amount of oxygen. Therefore metabolic activity in the body can be detected through the consumption of oxygen. Oxygen consumption reflects the physiological activities in utilizing nutrients in the body so that it can be an indicator of the efficiency of feed utilization. Giving thyroid flour as much as $10 \mathrm{mg} / \mathrm{head} /$ day or $20 \mathrm{mg} /$ day in the long tail longer time allegedly dpat increase oxygen consumption and heat production of the body.

Basal metabolic rate of the chickens treated skin giving as much as $30 \%$ of cassava in flour ration and injection well with $10 \mathrm{mg} /$ head / day or $20 \mathrm{mg} / \mathrm{head}$ / day of thyroid was not significantly different compared with the basal metabolic rate of chickens received the control treatment. This suggests that the energy requirements for basic life of the chickens of the same age and in the resting state are relatively similar. Compared with chickens from 7 days, the chickens have beumur 14 days showed oxygen consumption, heat production and the body's basal metabolic rate is higher. This shows an increase in metabolic activity with increasing age.

\section{B. Effect of Treatment on Performance of Broiler Chickens}

The effect of treatment rations containing cassava skin and thyroid powder on performance of broiler chickens are presented in Table III.

TABLE III: The AVERAGE TREATMENT EFFECT ON FEED INTAKE, Body

\begin{tabular}{|c|c|c|c|}
\hline \multirow{2}{*}{ Treatment } & \multicolumn{3}{|c|}{ Parameters observed } \\
\cline { 2 - 4 } & $\begin{array}{c}\text { Feed } \\
\text { consumption } \\
\text { (G / head / day) }\end{array}$ & $\begin{array}{c}\text { Added body } \\
\text { weight (kcal / } \\
\text { head / day) }\end{array}$ & $\begin{array}{c}\text { Efficiency } \\
\text { ration }\end{array}$ \\
\hline P1 (Control) & $27,160^{\mathbf{b}}$ & 21,914 & $0,822^{\text {ab }}$ \\
\hline $\begin{array}{c}\text { P2 (cassava skin } \\
\text { without steam) }\end{array}$ & $37,880^{\mathbf{a}}$ & 22,315 & $0,596^{\mathbf{b}}$ \\
\hline $\begin{array}{c}\text { P2 (skin on } \\
\text { steamed manioc) }\end{array}$ & $31,006^{\text {ab }}$ & 21,451 & $0,741^{\text {ab }}$ \\
\hline $\begin{array}{c}\text { P4 (Flour thyroid } \\
10 \text { mg / head / } \\
\text { day) }\end{array}$ & $32,725^{\text {ab }}$ & 21,050 & $0,676^{\text {ab }}$ \\
\hline $\begin{array}{c}\text { P5 (Flour thyroid } \\
\text { 20 mg / head / } \\
\text { day) }\end{array}$ & $24,840^{\mathbf{b}}$ & 21,176 & $0,917^{\mathbf{a}}$ \\
\hline
\end{tabular}

Description: Superscript lowercase letters are different at the same column indicate significantly different at the level of $(P<0,05)$.

Results of analysis of variance on feed consumption and feed efficiency showed that the treatment significantly $(P$ $<0.05$ ), whereas the body weight gain, the treatment had no significant effect $(P>.05)$. In general provision of rations containing cassava skin improve feed intake, although the treatment diet containing skin steamed cassava feed intake was not different compared to control treatment. Allegedly diet containing cassava peel contains higher crude fiber than other treatments because it is known cassava peel contains high crude fiber [4], so the reduced energy availability and increased feed intake to meet their energy needs.

Feed consumption of chickens that are treated thyroid flour giving as much as $10 \mathrm{mg} / \mathrm{head} /$ day and $20 \mathrm{mg} /$ head / day by injection is no different than the feed intake of chickens that received the control treatment. Although there is a tendency to get the previous results that the administration of thyroid metabolic activity but an increase in feed intake was not real. Allegedly giving a relatively short time causing feed intake did not differ significantly.

The results showed that body weight gain was not significantly different between treatments. Provision of rations containing cassava peel as much as $30 \%$ (both steamed and not steamed) did not reduce body weight gain, although known to contain HCN cassava skin which can cause poisoning and disturbance to growth. Similarly, the administration of thyroid powder as much as $10 \mathrm{mg} / \mathrm{head} /$ day or $20 \mathrm{mg} /$ day head, body weight gain was not significantly different from controls. Although there was a trend of thyroid administration can increase metabolic 
activity, some reports get mixed results, no one can improve body weight gain [5]-[7] but the reality weight gain not different from controls. Allegedly required a long time to be giving thyroid powder can provide metabolic stimulation.

The results get all the feed efficiency of the treatment was not significantly different from the control treatment, but demonstrated the highest efficiency in the treatment of thyroid flour administration of $20 \mathrm{mg} /$ head / day. Allegedly giving thyroid flour as much as $20 \mathrm{mg} /$ head / day can increase protein synthesis so that a more efficient use of feed. It is known that thyroid hormone stimulates the formation of protein networks, namely by increasing protein synthesis through increased RNA synthesis at the level of protein in the nucleus and cytoplasm [8]. Ration efficiency of the worst occurred in chickens treated diet containing cassava skin without steamed, and there kecendungan that the implementation of this diet containing cassava peel as much as $30 \%$ ration becomes inefficient. Allegedly there is a toxic effect of $\mathrm{HCN}$ that inhibit growth.

\section{CONCLUSION}

Provision of treatment rations containing cassava peel as much as $30 \%$ and as much thyroid powder injection $10 \mathrm{mg} /$ head / day and $20 \mathrm{mg} /$ head / day increase oxygen consumption and heat production of the body, while the rate of basal metablisme is not influenced treatment.

Metabolic activity of broilers increased concurrently with the increasing age characterized by increased oxygen consumption, body heat production and basal metabolic rate.

Giving skin treatment diet containing 30\% cassava flour and thyroid injection as much as $10 \mathrm{mg} /$ head / day tended to increase feed intake and feed efficiency decrease, whereas thyroid powder injection of $20 \mathrm{mg} /$ head / day will increase feed efficiency.

\section{REFERENCES}

[1] H. A. Harper, V. W. Rodwell, and P. A. Mayes, Review of Physiological Chemistry (Biochemistry), Translation by $\mathrm{M}$ Muliawan, 17th ed. CV.EGC. Book Medical Publishers, Jakarta, 1979, pp. 376.

[2] L. R. Steel and J. H. Torrie, Principle and Procedure Statistics, McGraw-Hill Book Company Inc., New York, 1980.

[3] P. McDonald, R. A. Edward, and J. F. D. Greenhalgh, Animal Nutrition, 2nd ed, The English Language Book Society and Longman, London, 1977, pp. 479.
[4] C. Devendra, "Source cassava as feed for ruminants," in Cassava as Animal Feed, B. Nestle and M. Graham Eds. IDRC, Canada, 1977, pp. 107-119.

[5] A. Atmomarsono, "Role of Thyroid Hormone in Relation to the Use of Protein Performances Broiler," dissertation, Graduate School of Bogor Agriculture Institute, Bogor, West Java, Indonesia, 1989, pp. $125-220$.

[6] J. D. May, "Effect of dietary thyroid hormone on growth and feed efficiency on broiler," Poult. Sci. vol. 59, pp. 882-892, 1980.

[7] C. E. Leung, J. E. Taylor, and V. Inderstin, "Effect of thyroid hormone on growth, feed efficiency and plasma T3 and T4 in 4 Week Old Cockerel," Poult. Sci., vol. 61, pp. 1500-1501, 1982.

[8] H. Astier, Thyroid Gland in Birds: Structure and Function. In: Avian Endocrinology. A. Epple and M. H. Stetson, Eds. Academic Press, New York, 1980, pp. 167-189.

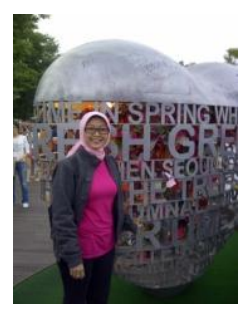

Yuanita Windusari was born on 14 September 1969 at Tanjungkarang, Province of Lampung, Indonesia, who received her bachelor's degree (Bachelor of Science) in the Department of Biology, Faculty of Mathematics and Natural Sciences, University of Sriwijaya in Palembang, South Sumatra, Indonesia in 1993. In 2002, she obtained postgraduate degree (M.Sc.) from Institute Technology of Bandung in Bandung, Indonesia in the field of Developmental Biology and Toxicology. In 2009 she followed the Sandwich-like programme include studies of wetlands in the UNESCO-IHE, Delft, Netherland. In 2012, get the title of Doctor from Environmental Science Programme, University of Sriwijaya in Palembang, South Sumatra, Indonesia for the general study is wetlands, while the dissertation study on the patterns of vegetation succession on land of tailings. Until now she has been active as a lecturer, researcher, and several university activities. She is also active as a researcher at "Research Center of Sub-optimal land Development of Sriwijaya University (PUR PLSO)". Many studies, symposium, seminar, training and workshops at the local, national and international have been followed. Was awarded as the best presentation and in 2013 was awarded the best presentation at the International Symposium of Lowland and Technology in Nusadua, Bali, Indonesia, organized the International Association of Lowland and Technology based in Saga University Japan. Recent research related to carbon stocks in forest vegetation in the city of Palembang, South Sumatra, Indonesia and the quality of the river waters. The results of these studies generally have been published in several journals nationally accredited.

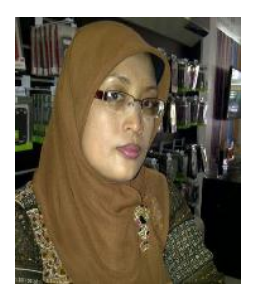

Meisji Liana Sari was born at Palembang on 27 May 1970. She has got her bachelor degree from Jambi university, South Sumatra Indonesia in 1994. In 2002, she has got her master degree from Bogor Agriculture Institute (IPB), West Java Indonesia. She got her Doctoral degree also from Bogor Agriculture Institute (IPB), West Java Indonesia in 2012. She is a lecturer at Nutrition and Animal Feed Department, Sriwijaya University (UNSRI). She is also active as a researcher at "Research Center of Sub-optimal land Development of Sriwijaya University (PUR -PLSO)'. 